289 KAMMA OVERGAARD HANSEN

Ph.d., ekstern lektor i kunsthistorie

Institut for Kultur og Kommunikation, Aarhus Universitet

\title{
BØRNEPENGE
}

\section{Om handel som netværksskabende aktivitet, særlige pengesedler og børn som forbrugere i Forschungstheaters Børnebanken}

På firkantede skamler sidder en lille flok børn i alderen 4 til 12 år med deres forældre eller bedsteforældre. Foran dem projiceres forskellige fotografier og små videosekvenser op på en hvid væg. En kvinde fortæller på engelsk om sine tanker om, hvordan man kan grundlægge sin egen bank. Hun fortæller også, at hun faktisk allerede har prøvet at grundlægge en bank sammen med en anden flok børn i en anden by. Kvinden holder jævnlige pauser i sin fortælling, hvor en yngre kvinde oversætter til dansk. Børnene og deres forældre lytter og kommer ind imellem med lavmælte grin. Der bliver sendt en pengeseddel rundt, som de kigger på.

Den engelsktalende kvinde forlader nu sine egne erfaringer med at grundlægge en bank. I stedet finder hun en dyremaske frem fra et podie bag sig. En mand kommer til og ifører sig en anden dyremaske. De to gennemspiller nu en lille episode, hvor en tyr hjælper en tudse med at skrabe jord væk, så tudsen kan få sin egen lille dam. Tudsen æder til gengæld de fluer, der generer tyren. Tyren bliver dog utilfreds med byttehandlen, da den mener, at arbejdsbyrden er ulige fordelt. Med hjælp fra en mus finder de to dyr en ordning, hvor tyren hjælper tudsen med at fjerne jord én gang mod at få tudsens hjælp til fluefangeriet tre gange. "Og i dét øjeblik blev pengene opfundet", slutter den dansktalende fortæller. De tre aktører spiller også 
andre episoder, der alle ender med, at dyr eller mennesker opfinder en form for valuta, der kan sættes i stedet for de ting, de har brug for.

Efter cirka tyve minutter lægger aktørerne rekvisitterne fra sig. Børnene og de voksne klapper og rejser sig fra skamlerne. De guides nu over til et stort arbejdsbord, hvor børnene efter en kort instruktion går i gang med at lave tredimensionelle collager. Forældre og bedsteforældre sidder også omkring bordet og får indimellem lov at hjælpe til. Når collagerne er færdige, går børnene hen til et andet bord. Her fotograferes deres collager. På en computerskærm kan børnene se affotograferingen af deres collage, og de får lov at vælge en baggrundsfarve. Børnene vælger også et navn til deres valuta, der i langt de fleste tilfælde - og med ivrig hjælpsomhed fra de voksne - bliver en afledning af barnets eget navn. Således bliver der i dagens løb produceret pengesedler med påskrifter som 100 sophitter, 100 mariunutter og 100 viggioner. Hvert barn får lov at trykke én pengeseddel, der til sidst bliver påstemplet et lille anker på bagsiden. Hermed er pengesedlen at regne for en officiel valuta, der kan omsættes til småtterier eller godter hos de lokale butikker, der har indvilget $\mathrm{i}$ at være med i denne udgave af Børnebanken. ${ }^{1}$

Vi er til den første åbningsdag i Børnebanken - et seks dage langt kunstprojekt, der med arrangørernes ord "leger med de regler og rammer, vi normalt tager for givet". ${ }^{2}$ Jeg vil i denne artikel analysere Børnebanken både som æstetisk værk og som normkritisk eksperiment. Det første, fordi Børnebanken i sin idé og scenografi er illustrativt for idealistiske forestillinger om børn, penge og handel. Og det andet, fordi Børnebanken med sit publikumsinddragende format er et 'ustyrligt' værk, der giver anledning til nogle interessante sammenstød mellem det ideologiske udgangspunkt og den praktiske virkelighed. Sammenstød, der kan bruges til at diskutere, hvordan vi i en relativt velstående vestlig kontekst opfatter os selv som aktører i et handels- og forbrugssamfund og ikke mindst, hvordan vi fore-

1 Beskrivelsen er baseret på egne observationer af Børnebanken på Horsens Kunstmuseum 13.-15.2.2017 samt på tyske manuskriptdele stillet til rådighed af Hannah Kowalski.

2 Citeret fra plakat for Horsens Happening designet af Liveart.dk, der havde inviteret Forschungstheater til Horsens. 
stiller os børns rolle heri. Artiklen vil således i ét perspektiv analysere Børnebanken som selvstændigt værk, mens den i et andet, bredere perspektiv vil forholde analysens pointer til aktuelle diskussioner om den relationelle æstetiks politik og handlens og pengenes historicitet.

Min beskrivelse af Børnebankens scenografi, praktiske udfoldelse og reception er baseret på egne iagttagelser; idet jeg havde mulighed for at observere de aktiviteter, der udfoldede sig indenfor dens rammer på Horsens Kunstmuseum i løbet af dens tre første åbningsdage. På Børnebankens tredje åbningsdag havde jeg desuden fået lov at følge én af Børnebankens brugere, Vigga på 11 år, både under hendes besøg i selve 'banken' og i hendes efterfølgende tur rundt til de medvirkende butikker. Én af de medvirkende butikker var museumsbutikken på Horsens Kunstmuseum, som ofte var det første sted, børnene gik hen efter at have trykt deres pengeseddel, og som jeg observerede løbende under mine tre besøg på museet. Endelig har jeg i mine beskrivelser støttet mig til manuskriptdele og notater fra én af Børnebankens grundlæggere og aktører, den tyske dramaturg Hannah Kowalski.

\section{EN BANK BLIVER TIL}

Børnebanken udspringer af Die Kinderbank, der første gang blev realiseret i Hamburg i 2012. Den danske titel kom til, da projektet blev lanceret på ARKEN Museum for Moderne Kunst i 2015, og videreførtes, da projektet flyttede ind på Horsens Kunstmuseum i vinterferien 2017. Værkets ophav er Forschungstheater; en konstellation af kunstnere, teaterfolk, kulturhistorikere og forskere, der i 2003 voksede ud af det eksperimenterende børneteater Fundustheater i Hamburg. Som en af stifterne, dr. phil. i litteratur og kulturhistorie Sibylle Peters, har formuleret det, handlede Forschungstheater i sit udgangspunkt om at undersøge, "om den viden, som produceres gennem kulturstudier, kan overføres til eksperimentelle situationer". I første omgang skabte hun et performativt setup, hvis formål var at undersøge tid og tidsstyrings betydning i samfundet. Som samarbejdspartner valgte Sibylle Peters en lokal skole ("et system indenfor hvilket de fleste af os lærer om tid"), og det direkte samarbejde med skoleeleverne blev skelsættende for hende: 
292 KULTUR \& KLASSE * $124 * 2017$

HANDEL

Den vigtigste opdagelse, jeg gjorde i dette studie, var børnene selv. [...] Det var mere, end jeg havde turdet håbe på: De var virkelig eksperter i at afdække de selvindlysende kulturelle mønstre; de mønstre, der er så vanskelige for os at få hånd om, fordi vi i forvejen udlever dem gennem vores liv (Peters 100-101). ${ }^{3}$

Erfaringerne fra projektet om tid kom til at danne grundlag for Forschungstheaters arbejdsmetode. Bag alle deres værker ligger således en procedure, der starter med litterær research og opbygning af scenografi, dernæst inddrager børn i rollen som eksperter gennem interventioner i deres hverdag, videreføres som interaktive præsentationer og afsluttes med afrapportering i form af oplæg og publikationer. Ud fra denne skabelon skabte Forschungstheater op gennem oo'erne og 10'erne en række projekter med afsæt i børns ønsker og drømme. Bl.a. fik en gruppe skolelever lov til at teste deres skoler og således vende op og ned på hverdagens hierarkier og lærer-elev-forhold (Kinder testen Schule, 2010).

Som en anden af Forschungstheaters stiftere, Hannah Kowalski, fortæller i sin introduktion til Børnebanken i Horsens, har der i Forschungstheaters møder med børn været ét ønske, der særligt ofte gik igen hos børnene; nemlig dét at være rig. ${ }^{4}$ Inspireret af alternative økonomier i bl.a. Brasilien - og i tæet samarbejde med en skoleklasse - opstod derfor idéen om at grundlægge en bank med egen seddelproduktion og eget netværk af lokale forretningsdrivende, der er villige til at omsætte den nye valuta til varer. Den første Abenteuergeld har siden fået følgeskab af andre børneskabte valutaer, og Die Kinderbank har i dag sin egen hjemmeside og åbner med jævne mellemrum nye filialer. ${ }^{5}$ Hver gang Die Kinderbank har været afviklet et nyt sted, har Forschungstheater samlet de medvirkende børn og forretningsdrivende til en afsluttende erfaringsudveksling. Indimellem har også forskere i fattigdom, politikere og andre aktører medvirket i denne fase (Peters 106).

Die Kinderbank er således ikke først og fremmest teater, men en løbende undersøgelse af de netværk, som handelssituationen skaber mellem mennesker. Som Hannah Kowalski har beskrevet, er ét af projektets mål

3 Egen oversættelse fra engelsk.

4 Kowalski i mundtlig introduktion til Børnebanken, Horsens Kunstmuseum, 13.2.2017 (egen oversættelse fra engelsk). Se også: Peters 104-105.

5 http://www.kinderbank-hamburg.de/Kinderbank/Home.html. 
netop at skabe muligheder for at interagere "ikke blot med venner [...], men tværtimod også med fremmede" i udvekslingen mellem børnenes pengesedler og butikkernes varer (Kowalski, manuskript til Børnebanken). ${ }^{6}$ Spørgsmålet er blot, om det er denne forbindelse til fremmede, der i første omgang tiltrækker såvel børnene som de forretningsdrivende. I det mindste tyder erfaringerne fra Børnebanken i Horsens på, at også andre faktorer har motiveret børnene.

Samtidig indgår der i Børnebankens scenografi elementer, der peger væk fra netværkstanken og mod et mere kritisk blik på bankvæsnet og handelslivets betydning. Scenografien udgør kernemålgruppens allerførste møde med Børnebanken. Inden vi ser nærmere på forholdet mellem Forschungstheaters formulerede intentioner og den praksis, som de i Horsens-udgavens tilfælde udmøntede sig i, vil vi derfor zoome ind på scenografien som æstetisk ramme og afsæt for aktiviteterne.

\section{HANDELSLIVETS SCENOGRAFI}

I den fjerde udgave af Die Kinderbank er børnenes bank indrettet i en stor, højloftet sal på Horsens Kunstmuseum. Her skal værket for første gang udfoldes over flere dage. En dansk dramaturg er hentet ind som formidler mellem det danske publikum og Forschungstheaters to tyske aktører, hvoraf den ene er Hannah Kowalski.

Børnebankens hovedsæde er i denne omgang et åbent rum med hvide vægge og lyse trægulve. Det grænser op til museets café, og stort set alle museets gæster stikker hovedet indenfor under deres besøg på museet. Ovenfor kan man fra en balkon kigge ned i rummet fra museets overetage. I det ene hjørne er der opstillet ti små skamler lavet af brune papkasser. Et skilt med det tyske Bertolt Brecht-citat "Was ist der Einbruch in eine Bank gegen die Gründung einer Bank?" hænger på væggen. Under skiltet er der opstillet et podie, hvorpå en række rekvisitter er sirligt opstillet: Tre dyremasker, en bog, en gigantisk ost af træ, en legetøjspistol, en sixpence, et bundt plantestilke, en sæk og en guldkugle - alle rekvisitter, der kommer i spil, når Børnebankens aktører introducerer dagens deltagere for deres koncept. 
294 KULTUR \& KLASSE * $124 * 2017$

HANDEL

I rummets anden ende er der gjort klar til at producere pengesedler: Her finder vi et stort arbejdsbord med farvet karton, farvede skumplader, pailletter, knapper, snore, mos, blade, piberensere og pomponer. Ved siden af arbejdsbordet står computer og printer parat. Langs væggene er der opstillet podier til at udstille de collager, der skal udgøre motiverne på børnenes personlige pengesedler. På væggen kommer et eksemplar af hver pengeseddel op at hænge, så den hvide vægflade i løbet af ugen dækkes af en omfattende papircollage.

Midt i rummet, på gulvet, er en miniaturemodel af Horsens' bymidte stillet op. Byens gader er angivet med blåt tape, og de medvirkende butikker er stillet op som små, nummererede papmodeller. Den blå tape illustrerer både vejenes forløb og gadehjørnernes vinkler, men danner også en form for netværk mellem Horsens Kunstmuseum og butikkerne. Et netværk, som vel at mærke opløses i blindgyder i området udenom butikkerne.

Anskuet som et værk i sig selv kan scenografiens tre afdelinger med henholdsvis teaterrekvisitter, kreative materialer og bymodellen på gulvet fortolkes som en visuel repræsentation af de forskellige ting, som penge er: Penge er således både noget, der fortælles; noget, der produceres; og noget, der skaber forbindelse mellem forskellige aktører. Hermed antydes det, hvordan vores hverdagslige omgang med penge beror på både noget meget konkret og noget meget abstrakt: På den ene side pengesedlen som noget, man kan holde i hånden, aflæse og bytte for noget andet. Og på den anden side penge som noget, der kun har en værdi, fordi vi gennem forskellige bestemmelser og ritualiserede handlinger tillægger dem en værdi.

En sådan tilgang til penge understreges yderligere, når Hannah Kowalski som de allerførste ord i sin indledning til Børnebanken på Horsens Kunstmuseum stiller spørgsmålet: "Hvad er en pengeseddel, når det kommer til stykket?" Et spørgsmål, som hun selv besvarer med ordene: "Det er papir. Og det er en aftale. Det er en kupon, der giver mig ret til at nyde godt af noget, vi, som samfund, har skabt sammen". ${ }^{7}$ I sin egenskab - og selvforståelse - af forskningsbaseret og forskende institution forekommer det nærliggende, at Forschungstheater med denne sammentænkning af pengeseddel, symbolværdi og netværk peger tilbage på nogle af de teori-

Egen oversættelse fra engelsk. 
dannelser, der har været normsættende indenfor deres tema; i dette tilfælde en marxistisk kapitalismekritik. Som vi senere skal se, er dét imidlertid en kritik, der kan nuanceres en del mere, end den umiddelbart bliver det gennem Forschungstheaters dramaturgi. Til gengæld synes den marxistiske afsmitning at cementere Forschungstheaters image som normkritiske og føje en vis akademisk aura til et setup, der ellers kunne forveksles med ren underholdning.

Kowalskis omtale af 'det store vi' ("vi, som samfund") peger således også på, at penge udgør et fællesskab, som man både kan være med i og udenfor. Dette står klart frem i hele Børnebankens setup, hvor kun 16 af byens forretninger medvirker (og hvor man i øvrigt fortrinsvis har spurgt forretningsdrivende, hvis sortiment forventedes at appellere til børn). Det understreges samtidig ganske tydeligt af bymodellen på gulvet, hvor de blå veje alene forbinder de butikker, der er med i Børnebanken, hvorefter vejene fører ud i ingenting. Tilsvarende kunne man også opleve forskellen mellem dem, der var 'inde', og dem, der var 'ude', på en gåtur gennem Horsens: Her skilte de medvirkende forretninger sig ud ved at have en særlig Børnebanken-sticker på vinduet. Denne forskel har naturligvis tjent et praktisk formål. Den kan imidlertid også anskues som en manifestation af, hvordan penge indgår i et lukket kredsløb, hvor kun de, der er i besiddelse af den rette valuta, kan indgå. Som vi afslutningsvis vil se på, gør dette i øvrigt Børnebanken til et i en vis forstand 'gammeldags' værk, eftersom det ikke tager højde for den stadige strøm af alternative betalingsformer.

For den umiddelbare betragtning er det fællesskab, som pengene giver os mulighed for at indgå i, kun positivt: Børnene i Børnebanken er 'med i legen', og pengene giver dem mulighed for at nyde godt af noget, som 'vi' har skabt sammen. Brecht-citatet på væggen peger imidlertid i retning af, at det fællesskab, som pengene er med til at skabe, ikke er at opfatte som noget positivt.

Oversat til dansk lyder citatet noget i retning af "Hvilken betydning har dét at røve en bank mod dét at grundlægge en bank?" Det peger således på, at det ikke ændrer noget særligt at røve en bank set i forhold til, hvor samfundsomvæltende det er at grundlægge en bank. Hos Brecht lyder fortsættelsen på citatet "Hvad er det at myrde en mand i forhold til at ansætte en mand?" Det provokerende spørgsmål udtales af gaderøvernes 
296 KULTUR \& KLASSE * $124 * 2017$

HANDEL

anfører Mackie Messer i Dreigroschenoper (på dansk: Laser og pjalter); et socialistisk værk fra 1928, der ganske utvetydigt kritiserer den kapitalistiske samfundsform. Citatets herkomst er omstridt; ${ }^{8}$ men dets budskab synes at være underliggende gennem hele Brechts stykke: at pengenes kredsløb er blevet så komplekst, at det åbner for hykleri og bedrag.

Når Forschungstheater vælger at inddrage et citat af Bertolt Brecht - og ovenikøbet et centralt citat fra netop dette stykke - er de rimeligvis fuldt bevidste om de kapitalismekritiske konnotationer, der følger med. Trods alt er Dreigroschenoper et berømt teaterstykke og Brecht en væsentlig dramatiker, som de med deres faglige baggrund umuligt kan have overset. De er således næppe blinde for, at en del af de forældre, der tager deres børn med i Børnebanken, vil opfatte inddragelsen af Brecht som et kritisk indspark. Et sådant synes dog i nogen grad at blive punkteret i Hannah Kowalskis introduktion til dagens aktiviteter.

I Kowalskis engelske introduktion til Børnebanken i Horsens omtales citatet blot ganske kort og forklares som "Lad være med at røve en bank, hvis du kan grundlægge én". ${ }^{9}$ Derpå følger en (tvivlsom) forklaring om, at banker ikke behøver at stjæle penge, men blot på forunderlig vis kan trykke nogle selv. I Kowalskis manuskript lyder det videre, at "for at grundlægge en bank [...] skal du være meget rig til at begynde med." En påstand, der dog straks tilbagevises med et eksempel på det modsatte; nemlig den brasilianske Banco Palmas.

Banco Palmas blev grundlagt i 1998 i en forstad til Fortaleza-Ceará i det nordøstlige Brasilien som et forsøg på at komme områdets udbredte fattigdom til livs. Formålet med Banco Palmas var at grundlægge en solidarisk økonomi med lige adgang for alle i form af mikrolån, mikroforsikring og efterhånden også sin egen lokale valuta. Idéen med lokalvalutaen Palmas er, at borgerne i Banco Palmas' lokalområde udelukkende kan handle med hinanden og således sikrer en vis omsætning blandt de handelsdriven-

8 Citatet udgør en senere tilføjelse til Brechts oprindelige manuskript og menes at være forfattet af Elisabeth Hauptmann, der oversatte stykkets engelske forlæg, John Gays The Beggar's Opera fra 1728, til tysk (Hinton 28-29).

9 Citeret fra Kowalskis engelske manuskript, hvor ordlyden er: "Don't rob a bank, if you can found one." 
de. ${ }^{10}$ Banco Palmas udgør dermed sit eget lille økonomiske mikrokosmos, og det er temmelig tydeligt, hvor inspirationen til Die Kinderbanks setup med lokale forretninger er hentet. Når en Palmas-seddel i introduktionen sendes rundt og vises til børnene, suppleres scenografiens hentydninger til Brechts kapitalismekritik altså med et mere nuanceret perspektiv på penge og handel: Et perspektiv, hvor det at blive inddraget i pengenes og handelens kredsløb skaber positive forandringer for mennesker (og pengenes kredsløb i øvrigt forbliver på et simpelt niveau i stil med det, Mackie Messer efterlyser).

Denne nuancering understøttes til dels af de dyrefabler, som aktørerne gennemspiller i introduktionen til Børnebanken. Herigennem iscenesættes nemlig en naturalisering af penge og handel som noget, der altid har været der og løser nogle praktiske problemer for dyrene. Dette synes at pege i en anden retning end Brecht-citatets kapitalismekritiske konnotationer. Spørgsmålet er, hvad denne flertydighed i forhold til sit emne, som Børnebanken og dens scenografi således repræsenterer, i grunden afspejler: Handler den alene om, at Børnebanken er en ramme for undersøgelse, og at Forschungstheater derfor nægter at indtage en klar holdning? Eller forestiller Forshungstheater sig, at de medvirkende børn før eller siden vil fa øjnene op for, at penge og handel kan anskues som både noget positivt og noget negativt? Er det sidste tilfældet, kræver det i det mindste, at Forschungstheater er åbne overfor, at børnenes opfattelse af positivt og negativt i denne sammenhæng er ude af Forshungstheaters egne hænder. I et publikumsinddragende værk er alle aktører, og alle bestemmer (noget). Dermed er vi inde ved kernen af den relationelle æstetiks største styrke - der selv sagt også er dens største problem, som vi snarest skal se.

\section{PUBLIKUMSINDDRAGELSENS USTYRLIGHED}

Relationel æstetik blev første gang introduceret som begreb i 1995 af den franske kurator og kunstkritiker Nicolas Bourriaud. Få år senere var han med til at stifte det alternative udstillingssted Palais de Tokyo, og i 2002

10 Banco Palmas' projektbeskrivelse på: https://www.changemakers.com/bankingonsocialchange/entries/palmas-bank. 
298 KULTUR \& KLASSE * $124 * 2017$

HANDEL

kuraterede han gruppeudstillingen Touch: Relational Art from the 1990es to Now på San Francisco Art Institute som den største af en række udstillinger indenfor det publikumsinddragende kunstfelt.

Bourriauds begrebsdefinition tager afsæt i en række publikumsinddragende og intervenerende "udvekslingsområder" (Bourriaud 17) iværksat af kunstnere som britiske Gillian Wearing (Confessional Pieces, 1990'erne) og danske Jens Haaning (Turkish Jokes, 1994). Disse kunstneres 'værker' (for så vidt som man kan kalde dem dét, eftersom Bourriaud modsætter sig forestillingen om kunstværket som begrænset til "dets materielle form" (Bourriaud 20)) "sætter menneskelige interaktioner i gang"; de iværksætter "en forhandling med det forståelige, det intelligible, som det er vor lod at have fået del i", og herigennem "indleder kunstneren en dialog" (Bourriaud 21-22). Ifølge Bourriaud er det bl.a. dét, der sker, når en gruppe tyrkere pludselig finder sig selv "forenet i en fælles latter" over de sjofle tyrkiske vittigheder, som Jens Haaning sendte ud gennem en højttaler opstillet i Oslos centrum i 1994 og i Kassel i 2002 (Bourriaud 16-17). At værket gjorde meget andet end 'at forene i latter' er en anden sag. Den forargelse, der fulgte med værket, gør det ikke mindre 'relationelt', for pointen er netop, at det iværksætter en reaktion og en aktivitet blandt sit publikum (Bourriaud 17; Jalving; Ring Petersen).

Den relationelle æstetik er således et kollektivt anliggende, der "går hinsides det private og autonome rum", som det hedder (Bourriaud 125). I stedet er værket "en varighed, der skal føles, efterprøves, som en åbning mod den ubegrænsede meningsudveksling" (Bourriaud 14). Relationel æstetik har således en del at gøre med dét, som den tyske professor i dramaturgi Erika Fischer-Lichte (f. 1943) har benævnt "the feedback-loop"; nemlig det fænomen, at performeren påvirker sit publikum, hvis reaktioner samtidig påvirker performerens præstation (Fischer-Lichte "Culture as Performance"3; Fischer-Lichte The Transformative Power of Performance. A new aesthetics 38-42, 51, 73-74). Fischer-Lichtes begreb er rettet mod performancekunsten med spektakulære eksempler som Marina Abramovics Lips of Thomas (1975), der endte med, at publikum stoppede performancen i affekt over at se Abramovic ligge blødende på en isblok. Fischer-Lichte betoner imidlertid, hvordan interaktionen mellem det, vi traditionelt har forstået som henholdsvis kunstneren/performeren og publikum, i princip- 
pet altid er afgørende. I et projekt som Die Kinderbank synes denne relation at være endnu mere afgørende, eftersom en del af værkets præmis netop er børnenes deltagelse, og børnene (i det mindste den gruppe skoleelever, der i sin tid var med til at udvikle konceptet) i øvrigt tillægges en stor del af ansvaret for, hvordan deres egen bank skal være. En indvending i forhold til Børnebanken i Horsens kunne være, at projektet forekom temmelig tilrettelagt i udgangspunktet: Det var Forschungstheater selv, der præsenterede idéen for børnene, kontaktede de lokale forretninger og satte rammerne for, hvordan og med hvilke midler pengesedlerne skulle fremstilles. Ikke desto mindre har Forschungstheater været afhængige af tilfældighedernes spil i forhold til, hvem og hvor mange der ville dukke op i løbet af de seks dage, hvor Børnebanken var åben i Horsens.

På sin første åbningsdag forløber Børnebankens procedure omtrent som beskrevet $\mathrm{i}$ indledningen. Allerede næste dag falder proceduren imidlertid fra hinanden, da mere end 50 børn med deres voksne møder op i Børnebankens lokale. Den lille seance med fortælling og små skuespil må opgives, da børnene i en lind strøm søger mod arbejdsbordet. Hele dagen trykkes der pengesedler, børnene står længe i kø, og forældrene begynder at se trætte ud. Uforandret er til gengæld børnenes iver, når de efter endt besøg i Børnebanken søger ud i den nærmeste af de tilmeldte butikker, som er museumsshoppen på Horsens Kunstmuseum. Udvalget af sæbebobler, blyanter og andre småting studeres, mens børnene sammen med deres forældre overvejer, om de alligevel hellere vil omsætte deres pengeseddel til frozen yoghurt i Yoghurtland eller se på udvalget hos BR. I den efterfølgende evaluering melder de butiksansatte da også tilbage, at de har haft mange besøg af børn, der gerne lige ville se på varerne, inden de besluttede, hvad deres pengeseddel skulle bruges til (Kowalski, manuskript til Børnebanken, 18. februar 2017).

Forschungstheater tvinges altså til at indrette sig efter omstændighederne og har efterfølgende tilkendegivet en vis frustration over den store mængde børn, der mødte op på bankens anden åbningsdag. Bortset fra denne ene dags spidsbelastning synes den 'ustyrlighed' og interaktion, som værkformatet lægger op til, dog primært at have været et anliggende mellem børnene, deres forældre og de lokale forretningsdrivende. Så længe børnene opholdt sig i Børnebankens lokale, var de i princippet underlagt 
Forschungstheaters egen styring af, hvad der skulle foregå. Til gengæld har Forschungstheater ikke haft mulighed for at styre, hvad børnene reelt oplevede i værket. Sammenlægger man børnenes collager og deres iver efter at fremvise såvel pengesedler som indkøb og fortælle om den kreative proces, kan man f.eks. overveje, om værket reelt har vist os mere om børns æstetiske sans, deres evne til at udtrykke sig kreativt og deres indkøbsønsker. Det er med andre ord diskutabelt, om den normkritiske tilgang til omverdenen, som Forschungstheater tillægger børnene, eksisterer som andet end en gruppe idealistiske voksnes kunstneriske drøm.

Hermed er vi fremme ved en af de kritiske indvendinger, som den relationelle æstetik har været genstand for; nemlig dén, som kunsthistorikeren Claire Bishop har formuleret. I sin artikel Antagonism and Relational Aesthetics fra 2004 oplister hun en række problemer ved Bourriauds begreb og ikke mindst den måde, kunstens institutioner har taget det til sig på: At den relationelle æstetiks kunstnere snarere er en slags designere, at udstillingsstedernes kuratorer (ikke mindst Bourriaud selv) iscenesættes som de virkelige stjerner på kunstscenen, og at den æstetiske oplevelse for så vidt bliver sekundær til fordel for en mere 'oplevelsesøkonomisk' tilgang til kunst (Bishop 52-53). Væsentligst i denne sammenhæng sætter Claire Bishop desuden spørgsmålstegn ved, hvad det er for en type fællesskaber, den relationelle æstetik i grunden etablerer:

Kvaliteten af fællesskaberne i 'relationel æstetik' bliver aldrig undersøgt eller problematiseret. [...] alle relationer, der giver anledning til 'dialog', regnes automatisk for at være demokratiske og dermed gode. Men hvad betyder 'demokrati' i grunden i denne sammenhæng? Hvis relationel kunst etablerer fællesskaber mellem mennesker, må det næste logiske spørgsmål være: hvilke former for fællesskaber bliver etableret, for hvem og hvorfor? (Bishop 65). ${ }^{11}$

Bishop fremlægger herefter en række eksempler på værker, der hos Bourriaud præsenteres som eksemplariske for den relationelle æstetik. Alle er værker, der giver anledning til dialog og interaktion, men - som Bishop fremhæver - fortrinsvis mellem mennesker af samme slags. Hermed påpeger hun en risiko for, at den relationelle æstetiks publikum er så segment- 
specifikt, at der reelt ikke opstår nye 'demokratiske' indsigter på tværs af generationer, køn og samfundsklasser, men snarere etableres en bekræftelse af egne selvbilleder og holdninger.

I tilfældet Børnebanken kan vi med Bishop overveje, om ikke de børnefamilier, der måtte gå fra Horsens Kunstmuseum med et kritisk og velreflekteret syn på penge og handel, er familier, hvor far og mor allerede er bekendte med kapitalismekritiske teoridannelser, og hvor børnene er vant til, at der stilles spørgsmål ved samfundets normer. Vi kan videre overveje, om der med Børnebanken desuden etableres en brugergruppe, for hvem dyrefabler, pengeseddelproduktion og butiksbesøg har været ren underholdning. Ikke mindst kan vi overveje, om de to beskrevne brugergrupper har interageret med hinanden overhovedet. Og ligeledes kan vi spørge, om de medvirkende butikker har medvirket på baggrund af kritisk refleksion eller i forventning om at opnå gratis reklame.

Sådanne bevæggrunde burde ifølge Bourriauds ræsonnement være lige gyldige; lige 'demokratiske'. Men vi kommer næppe udenom, at tilstedeværelsen af mindre 'finkulturelle' motivationer - i dette tilfælde børnenes adfærd som forbrugere, forældre og bedsteforældres forventning om gratis underholdning og butikkernes formodning om øget goodwill og heraf øget omsætning - samtidig tydeliggør Forschungstheaters bagvedliggende intention om at fremme børnenes normkritiske blik på deres omgivelser lige lovlig meget. Hermed kan man spørge, om et stykke relationel æstetik som Børnebanken i sidste ende søger at kontrollere de børn og de fællesskaber, hvis åbenhed og kritiske potentiale det ellers hylder.

\section{DET NORMKRITISKE BARN}

Med sine referencer bagud til Brechts kapitalismekritik og måske også til en mere overordnet systemkritik synes Forschungstheater at cementere Børnebankens status af normkritisk værk. Sandt er det da også, at de aktiviteter, som børnene inddrages i, når de besøger Børnebanken, er illustrative for, hvad penge er og kan. Til gengæld er det en overvejelse værd, om de spørgsmål, som barnet eventuelt stiller i sit møde med Børnebanken, primært er brugbare for den voksne aktør. Her følger en genfortælling fra 11-årige Vigga, der besøgte Børnebanken i Horsens på dens tredje åbningsdag: 
vi startede med at få lidt og vide om hvorfor de startede projektet, det var bland andet fordi at de gerne ville have folk til at tænke over hvorfor man ikke bare kunne printe ens penge selv og de tænkte at den bedste måde at få tænkt over det var at lave en børne bank. Det var i hvert fald sådan jeg forstod det. Så gik vi i gang med at lave en form for collage som blev til baggrunden altså ligesom der nogle gange er broer eller sådan noget på penge. Man kunne bruge en helt masse forskellige materialer f.eks. snor, papir, små pompomer, knapper og paillet figurer (de kan være dyr eller blade og i en masse forskellige farver). Ens collage måtte gerne være tredimensionel for når man var færdig, tog de et billede af ens collage (man kunne selv vælge baggrunds farve). Så printede de pengene og skrev pengenes navn i toppen og så har man en fin lille seddel/ penge seddel. der var også en lille introduktion hvor de også fortalte nogen historier om hvordan man "skabte" penge, det var ikke sket i virkeligheden. Jeg syntes at det var et rigtig sjovt projekt og jeg syntes også det var sjovt at være med til. ${ }^{12}$

Læser vi Viggas beskrivelse som en øjenvidneberetning, skinner det ganske klart igennem, hvordan de voksnes roller i Børnebanken har adskilt sig fra barnets. I sin genfortælling lægger Vigga vægt på at fortælle, hvordan pengesedlerne blev fremstillet. I denne procedure synes Forschungstheaters dramaturgiske indslag at indgå som en form for introduktion til dagens egentlige opgave. Dette ligner formentlig en situation, hun kender fra skolen, hvilket også understreges af formuleringer som "Man kunne", "måtte gerne" og "det var i hvert fald sådan jeg forstod det". Disse ordvalg indikerer, at Vigga er gået til Børnebankens setup med en elevtilgang, hvor de voksne forventes at styre ud fra en forudbestemt agenda. De voksnes rolle som ledere understreges yderligere af vendinger som "de ville gerne have", "de tænkte", og "de fortalte".

Med en alder på 11 år hører Vigga til den ældre del af Forschungstheaters målgruppe. Det ses også af hendes genfortælling, hvor hun meget klart skelner mellem idé, fantasi og virkelighed. Og det er signifikant, at fantasien her er lagt i hænderne på de voksne, der i introduktionen har fortalt historier, der "ikke var sket i virkeligheden". Overfor de voksnes 'vilde' fantasi i form af ikke-virkelige dyrefabler står barnets fantasi og kreativitet, som i denne udgave af Die Kinderbank synes at være en meget 'styret' fantasi, eftersom den primært kommer til udfoldelse i barnets ud-

12 Vigga fik til opgave at nedskrive sin oplevelse af Børnebanken få timer efter sin medvirken, men inden hun brugte sin pengeseddel. 
formning og navngivning af sine egne pengesedler. De refleksioner, som Vigga har om penge, handler således mere om, hvordan penge kan se ud ("der er nogle gange broer eller sådan noget på penge"), end om, hvordan og hvorfor penge bruges. Forschungstheaters forestilling om barnet som særligt åbent (Peters 112) ${ }^{13}$ synes således ikke at komme til udtryk her.

Desuden er det interessant at se, hvordan pengene for børnene bliver en særlig ting i kraft af den æstetiske proces, de gennemgår, når de designer deres pengeseddel. I nogle tilfælde er børnene også på det rene med, at Børnebankens stempel sikrer pengesedlen dens gyldighed som valuta. Til gengæld lader der ikke til at ske nogen særlig udvidelse af 'særlig ting'-dimensionen for børnene i det øjeblik, de bruger deres pengeseddel til at handle med. I den situation er pengesedlen snarere en værdikupon, der kan omsættes til en vare - fuldstændig som Hannah Kowalski siger i starten af sin introduktion.

Tankevækkende er også børnenes syn på de varer, de kan omsætte deres penge til: På sin tur gennem Horsens kommenterer Vigga eksempelvis, at nogle af butikkerne har set Børnebanken som en anledning til at komme af med varer, de ikke har kunnet sælge under normale vilkår. Således indtræffer den lidt paradoksale situation, at det bliver forbrugersamfundets levninger, der indgår i det kunstprojekt, der skal lære børnene at forholde sig (endnu mere) kritisk til handel og forbrug. Med andre ord opstår der et misforhold mellem børnepengene som særlige ting, som børnene har gjort sig umage med at lave, og vareudbuddet, der fremstår som rester, som butikkerne søger at 'skille sig af med på en pæn måde'. Og samtidig afsløres børnene som endog ganske kritiske forbrugere, der så at sige ikke tager hvad som helst for gode varer.

Dette clash mellem Forschungstheaters forherligelse af barnets åbne sind og heraf kritiske spørgen til handelens præmisser på den ene side og projektets afsløring af børnene som 'kritiske forbrugere' på den anden side ekkoer af de diskussioner og undersøgelser, der i sin tid fulgte i kølvandet

13 Peters skriver: "vi kan skabe performative setups, som er i stand til at generere og skabe sociale og kulturelle opfindelser, før de er strukturelt implementeret. Og hvem vil i sidste ende være en bedre partner i denne form for eksperimenter end børn og unge?" (egen oversættelse fra engelsk). 
304 KULTUR \& KLASSE *124*2017

HANDEL

på den engelske anarkist, forfatter og kunstkritiker Herbert Reads efterkrigshyldest til barnets frie kreativitet i Kunstens græsrødder. Reads essay om det frie barns frie kreative udfoldelse foregreb nogle af de træk, der senere skulle blive definerende for reformpædagogikken. Her er barnets egne erfaringer i centrum for læreprocessen; men som kritiske røster siden har fremsat, var de 'frie' børn ofte tilbøjelige til at efterligne ældre børns tegninger eller populærkulturens billeder, når de blev bedt om at udtrykke egne erfaringer visuelt (Holm Sørensen 10-11). På lignende vis kan man overveje, om børnenes tilgang til handelssituationen i Børnebanken ikke i særlig grad afspejler en fri og naiv 'børnetilgang', men snarere en efterligning af de voksnes forbrugeradfærd.

I sine undersøgelser af pengenes betydning gennem historien åbner den argentinsk-amerikanske sociolog Viviana A. Zelizer imidlertid for et mere komplekst syn på penge, der måske kan bidrage til at forklare den drevne forbrugeradfærd, der karakteriserede mange af Børnebankens brugere. Som Zelizer påpeger, har der siden Karl Marx hersket en konsensus om penge som "market money", hvis rolle først og fremmest er at opretholde en moderne, handelsbaseret samfundskonstruktion. I sin nuancering af denne såkaldt "klassiske" forståelse af penge introducerer Zelizer sit begreb om "special monies", hvis betydning varierer efter og transformeres gennem de kontekster, de indgår i (Zelizer 342). Penge er, ifølge Zelizer, således "hverken kulturelt neutrale eller moralsk usårlige. De kan ganske vist 'fordærve' værdier til tal, men værdier og følelse fordærver samtidig pengene ved at tildele dem moralske, sociale og religiøse betydninger" (Zelizer 347-348). ${ }^{14}$ Følgelig knytter der sig også specifikke betydninger til de penge, børn af den ene eller anden årsag får mellem hænderne.

Som Zelizer beskriver, tilhørte børn og penge tidligere to forskellige sfærer, som fortrinsvis blev bragt sammen med et opdragende formål for øje. Det sene 1800-tals og tidlige 1900-tals børn fik måske nok lommepenge; men i så fald blev pengene "defineret primært som oplysende penge, der skulle lære børnene de rette sociale og moralske værdier såvel som at styrke deres evner som forbrugere" (Zelizer 370). ${ }^{15}$ Vi kan med en vis rimelighed

15 Egen oversættelse fra engelsk. 
overveje, om ikke det er en lignende agenda, der ligger bag Forschungstheaters koncept i Horsens anno 2017. Ganske vidst er der andre 'moralske og sociale værdier' i spil i dag, og forbrugerrollen omkring forrige århundredeskifte har måske i højere grad handlet om at skaffe brød på bordet og i heldigste fald få sine penge til at yngle; men det 'opdragende' sigte synes fortsat at leve i bedste velgående i Børnebanken. Forschungstheater må nødvendigvis tage højde for, at tyske og danske børn af i dag ikke er fuldstændig uvante med at have deres egne penge. Derfor giver det desto mere mening at guide børnene til at skabe nogle helt særlige penge, der er deres egne i højere grad end almindelige lommepenge. På den baggrund virker det faktisk også fuldstændig logisk, at de børn, der har trykt pengesedler i Børnebanken, ikke vil spilde deres individuelle variant af 'special monies' på hvad som helst. Uagtet at børnenes forbrugeradfærd formentlig afspejler forældrenes, kan vi ikke udelukke, at børnene faktisk også honorerer Forschungstheaters relativt omstændelige setup - pengesedlernes lange tilblivelsesproces med fortælling, collager, valg af baggrundsfarve, print og stempel - ved at handle med større omhu end normalt.

\section{FRA USKYLDIG UNDREN TIL KRITISK FORBRUGERADFÆRD}

Børnebanken i Horsens har i sit udgangspunkt haft til formål at tydeligg øre og diskutere vores forhold til penge og de regler, hvormed vi handler med hinanden. Dette er formentlig lykkedes i nogen grad, i og med at de medvirkende børn og deres voksne har beskæftiget sig indgående med emnet en halv til en hel dag. Om de i den forbindelse er nået til et egentligt kritisk syn på de økonomiske spilleregler, vi alle lever under, er nok mere tvivlsomt. Som en far bemærkede ved museets skranke efter at have lavet pengesedler med sit barn, nærmer selve Die Kinderbanks koncept sig forældelse, eftersom den klassiske vare-i-bytte-for-penge-situation i stigende grad afløses af dankort, MobilePay, online-handel og bitcoins. Rejsende i Tyskland vil formentlig have konstateret, at en del forretninger i Forschungstheaters hjemland fortsat sværger til kontantbetaling. Ikke desto mindre omfatter den anskueliggørelse af pengenes kredsløb, som Die Kinderbank lægger op til, kun en beskeden del af det felt, den søger at diskutere. 
306 KULTUR \& KLASSE * $124 * 2017$

HANDEL

For så vidt kan Børnebanken opfattes som et nostalgisk værk, der vækker mindelser om barndommens legen købmand. Ganske vist peger Forschungstheaters setup på handel som netværksskabende; men Børnebanken synes samtidig at pege mod et langt mere simpelt netværk end dét, der omgiver dens målgruppe i dag. Med Banco Palmas som en mulig og strålende undtagelse kan vi overveje, om den simple handelssituation, som Forschungstheater lægger op til, nogensinde har eksisteret. Og videre om den normkritik, som Forschungstheater ønsker at fremme, i grunden omfatter nogle normer, som danske børn anno 2017 kan genkende.

Forschungstheaters ideologiske og idealistiske afsæt, hvor en marxistisk-kapitalismekritisk tilgang til penge og handel krydres af ønsket om at bedrive normkritik og forestillingen om børns særlige evne til netop dette, synes i det mindste at kollidere med målgruppens respons på Børnebankens setup. Værkets "åbning mod den ubegrænsede meningsudveksling", som beskrives hos Bourriaud, udmønter sig måske nok i etableringen af en form for fællesskab mellem de deltagende børn og de voksne, der efterfølgende betjener dem i forretningerne. Men frem for at reflektere over bank- og handelsvæsnet synes børnene først og fremmest at have hæftet sig ved misforholdet mellem den omhyggeligt fremstillet pengeseddel og det til tider sløsede vareudbud; mellem deres egen omhu og de voksnes sjusk. Med Bishops kritik af den relationelle æstetik in mente kan vi her overveje, om den forkromede samfunds- og normkritik, som Forschungstheater søger at facilitere, primært har været et anliggende for en mindre gruppe af højtuddannede forældre og bedsteforældre, der under deres besøg i Børnebanken er blevet mindet om en kapitalismekritisk fagtradition og styrket i en forhåndsforståelse af sig selv som reflekterede og 'normkritiske'.

Vi har set, hvordan Børnebanken på godt og ondt ligger under for den ustyrlighed, der følger med det publikumsinddragende format. Det synes at være i modstrid med Forschungstheaters egne forventninger, at de medvirkende børn i vid udstrækning viste sig at være kritiske forbrugere snarere end forundrede normkritikere. På den anden side virker det rimeligt, når Vigga med en vis misbilligelse konstaterer, at den pengeseddel, som hun har brugt tid på at designe, skal byttes mod tilfældige dimser fra butikkernes restlager. Og vi kan med Zelizer overveje, om ikke Forschungstheater i denne udgave af Børnebanken faktisk har formået at genetablere det opdra- 
gende sigte, som fulgte med tidligere tiders lommepengeudbetalinger - og som måske til en vis grad stadig gør sig gældende blandt børnefamilier: En pengeseddel fra Børnebanken bliver ganske vist ikke sparet op til et senere og højere formål; men den bruges med omhu. Følgelig har vi at gøre med en slags 'fordrejet marxisme', hvor det ikke er varen, men pengesedlen selv, der feticheres. Børnebankens børn ved godt, hvad de er værd - måske ikke som arbejdskraft, men som betalere og forbrugere.

KAMMA OVERGAARD HANSEN. Ph.d., ekstern lektor ved Afdeling for Kunsthistorie, Institut for Kultur og Kommunikation, Aarhus Universitet. Har i maj 2017 forsvaret ph.d.-afhandlingen "Vi har ikke noget at sige, men vi gør det så koncentreret som muligt" - De Unge Vilde i dansk kunst. Såvel ph.d.-afhandlingen som nærværende artikel er blevet til under et forskningssamarbejde mellem Aarhus Universitet og Horsens Kunstmuseum.

\section{CHILDREN'S MONEY}

On Trade as Network-Building Activity, Special Monies, and Children as Consumers in Forschungstheaters Kinderbank

This contribution analyzes the interactive art project Die Kinderbank as it was displayed by the German Forschungstheater at Horsens Art Museum under the Danish title Børnebanken in February 2017. Børnebanken is analyzed as aesthetical art work as well as norm-critical experiment. The first, because the concept and scenography of Børnebanken can be seen as illustrative for idealistic conceptions of children, money, and trade. And the second, because Børnebanken with its interactive format is a potentially 'uncontrollable' work, which might lead to interesting clashes between the ideological point of departure and the practical reality. Clashes, which can be used to discuss, how we - in a relatively wealthy Western context - see ourselves as participants in a society of trading and comsuming, and not least how we imagine the role of our children in this society.

My analysis addresses, how Forschungstheater in their set-up points towards a Marxist-socialist critique of capitalism as illustrated by Bertolt Brecht as well as a more complex concept of money as a concrete, society-constituting and -consolidating symbol as described by Viviana A. Zelizer. It also discusses how Børnebanken as an example of Nicolas 
308 KULTUR \& KLASSE * $124 * 2017$

HANDEL

Bourriaud's concept of Relational Aesthetics is a work beyond our control. On that note, I ask the question of to what extend the discussions of money as societal phenomenon reach the primary target group: the children. My point is that the reactions of the children on the set-up of Børnebanken might point toward a critical consumer-behaviour rather than a norm-less curiousity.

\section{KEYWORDS}

DK: Forschungstheater; Relationel æstetik; Penge; Børn som forbrugere; Normkritisk tilgang til samfundsstrukturer

EN: Forschungstheater; Relational Aesthetics; Money; Children as consumers; Normcritical approach to societal structures

\section{LITTERATUR}

Banco Palmas' projektbeskrivelse. 29. juni 2017: https://www.changemakers.com/bankingonsocialchange/entries/palmas-bank.

Brecht, Bertolt. Die Dreigroschenoper/von Bertolt Brecht nach John Gay's 'The Beggar's Opera'. Berlin: Edition Suhrkamp, 1968.

Bishop, Claire. "Antagonism and Relational Aesthetics". OCTOBER 110 (2004): 51-79.

Bourriaud, Nicolas. Relationel æstetik. København: Det Kongelige Danske Kunstakademi, 2005.

Fischer-Lichte, Erika. The Transformative Power of Performance. A new aesthetics. London \& New York: Routledge, 2008.

Fischer-Lichte, Erika. "Culture as Performance". Modern Austrian Literature 42: 3 (2009): 1-10.

Hinton, Stephen. Kurt Weill: The Threepenny Opera. Cambridge: Cambridge University Press, 1990.

Holm Sørensen, Birgitte og Ingelise Flensborg. Temaer i billedpædagogik. København: Gad, 1997.

Imagination for people. Banco Palmas. Local currencies in Brazil's favelas. http://imaginationforpeople.org/en/project/banco-palmas/

Jalving, Camilla. "Kunst på grænsen". Kristeligt Dagblad 19. juni 2002 https://www.kristeligt-dagblad.dk/kultur/kunst-p\%C3\%A5-gr\%C3\%A6nsen

Kowalski, Hannah. Manuskript til Børnebanken: Introduktion og to skuespil: Der Bulle, die Maus und der Frosch og Der Bulle und die Kröte. Videregivet pr. mail af Hannah Kowalski, 29. marts 2017.

Kowalski, Hannah. Manuskript til mundtlig opsamling på Børnebanken på Horsens Kunstmuseum, lørdag d. 18. februar 2017. 


\section{KAMMA OVERGAARD HANSEN BØRNEPENGE}

Peters, Sibylle. "Participatory Children's Theatre and the Art of Research: The Theatre of Research/Das Forschungstheater 2003-2013". Youth Theatre Journal 27 (2013): 100112. http://dx.doi.org/10.1080/08929092.2013.837693

Read, Herbert. Kunstens Græsrødder. København: Wivels Forlag, 1949.

Ring Pedersen, Anne. "De usynlige etniske grænser". Information 25. juli 2003 https:// www.information.dk/debat/2003/07/usynlige-etniske-graenser

Zelizer, Viviana A. "The Social Meaning of Money: 'Special Monies'". American Journal of Sociology 952 (1989): 342-377.

Die Kinderbank, 29. juni 2017: http://www.kinderbank-hamburg.de/Kinderbank/Home. html 
310 KULTUR \& KLASSE * $124 * 2017$ HANDEL 